\title{
DIE ONTWIKKELING VAN DIE VROU AS SOLDAAT
}

\author{
LT E. M. MEYERS (SAV)*
}

\begin{abstract}
Through the ages there have been many examples of women soldiers. The legendary Jeanne d'Arc is quoted as a classic example, the Maid of Saragossa as an example wrt Spain and the legendary Queen Mantitisi of the Batlokwa (Sotho) tribe as another. Other countries such as Israel, for example, also had their share of women soldiers and examples of these are also discussed. Tendencies and developments in this field are analysed and the ultimate conclusion is reached that since the first World War, women have become more and more involved in military conflicts (albeit in a supporting role). America is quoted as an example of a country where many voices have been raised in favour of using women in a fighting capacity. The question now arises: will women eventually regain the role of Jeanne d'Arc of yore.
\end{abstract}

\section{Inleiding}

Sedert die begin van die vyftiende eeu was die vegtende vrou ' $n$ element waarmee geskiedskrywers rekening moes hou. Avontuurlus en 'n gevoel van patriotisme het haar die wapen laat opneem hoewel sy haar aanvanklik as manlike soldaat vermom het en so onopgemerk saam met haar man of geliefde op ' $n$ veldtog kon vertrek. Meeste vroue in manlike mondering moes die gevegsmagte verlaat sodra hulle as vrou ontmasker is. Tog was daar vroue wat op grond van hul persoonlike invloed oor die troepe sukses behaal het.

Die vrou van die vroeg-twintigste eeu het om ander redes as haar voorgangers uniform gedra. Gedurende die twee Wêreldoorloë is sy in die Weermag se ondersteuningsdienste sowel as in die industrie en in die landbou aangewend sodat alle weerbare manne vir gevegsdiens beskikbaar kon wees.

Vandag verander die situasie al weer aangesien vroue aktief meedoen aan guerrilla-oorlog, geslote militêre loopbaanmoontlikhede vir die vrou oopgaan en die kwessies of vroue gevegsopleiding moet kry en in gevegseenhede opgeneem moet word tans 'n ope vraag is. Indien die Amerikaanse vrou hierdie stryd wen, sal die vrou kort voor lank terug wees waar Jeanne d'Arc vyf eeue tevore begin het - op die slagveld.

\section{Die vegtende vrou: Voorbeelde in verskeie lande}

Die legendariese Jeanne d'Arc wat die wapen teen die Engelse troepe opgeneem het, was die eerste alleenstaande vrouekryger. As aanvoerder van die Franse troepe was sy in ' $n$ wit harnas gekleed en met ' $n$ lans, strydbyl en swaard gewapen. Sy het nie veel met die troepebewegings ingemeng nie, maar was tog die morele steun vir haar soldate. As gevolg van haar geweldige invloed oor die troepe is sy deur koning Karel as ' $n$ waardevolle militêre aanwins beskou. In 1431 het sy op die brandstapel vir Frankryk gesterf. ${ }^{1}$

Angelique Brulon, nog 'n Franse meisie, het tussen 1792 en 1799 in sewe veldtogte onder haar landsvlag geveg. Hoewel haar manlike vermomming ontdek is, is sy toegelaat om haar militêre diens voort te sit aangesien haar optrede so uitstaande was. Sy het by die leër aangesluit sodat sy in dieselfde regiment kon dien as dié waarin haar man gesterf het en haar vader steeds diens gedoen het. ${ }^{2}$

'n Manifestasie van die vrou se betrokkenheid op die slagveld is die ontdekking dat Paryse meisies na die slag van Waterloo onder die gesneuweldes getel het. Sir Walter Scott het hieroor gesê 'One morning when passing through the Palais Royal at Paris I saw a woman dressed in a military costume with boots, spurs and sabre. No Frenchman seemed to consider the sight a strange one'. ${ }^{3}$

Spanje se beroemdste vrouevegter was die Meisie van Saragossa. Sy is deur die admiraal as 'n militêre karakter beskou, na aanleiding van haar aandeel in die stryd teen die Franse in die Spaans-Napoleontiese Oorlog aan die begin van die negentiende eeu. Sy het ' $n$ pensioen van haar regering asook die betaling van " $n$ artilleriesoldaat ontvang. ${ }^{4}$ 


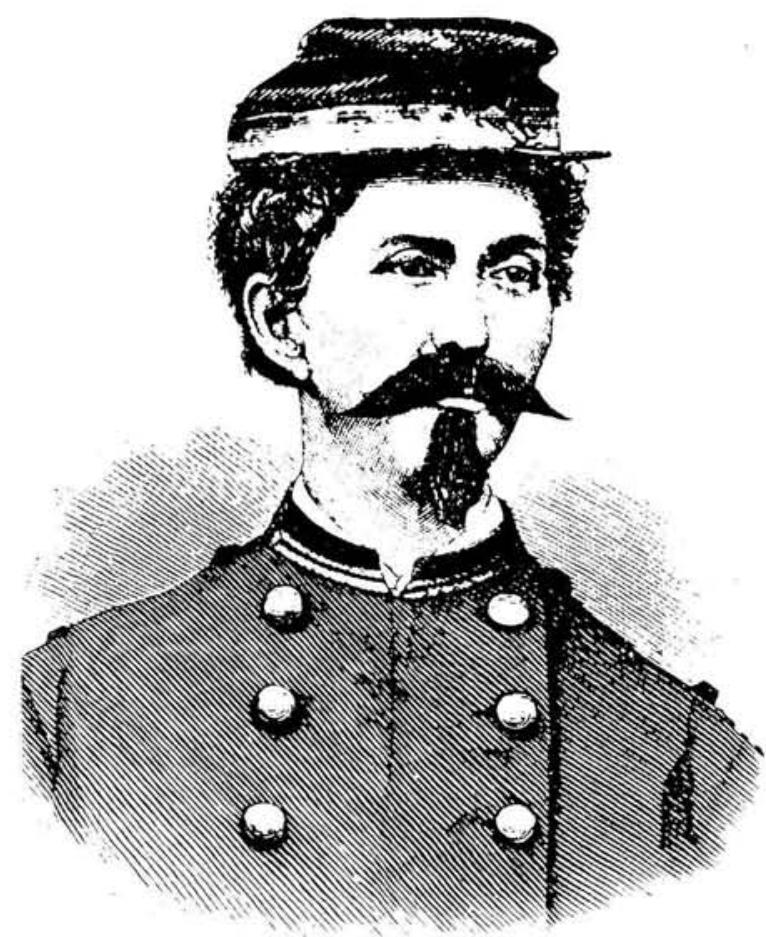

Loreta Valasquez vermom as 'n offisier van die Konfederale Leër. - Foto: 'Women in Battle' deur John Laffin.

Die Engelse vrou was spoedig reeds by die verdediging van haar land betrokke. So vroeg as 1761 het die Jaarlikse Register aangetoon dat Engelse vroue wat hulle mans op die slagveld gevolg het deur ' $n$ uniform aan te trek, uitgevind is. $^{5}$

Die Amerikaanse Vryheidsoorlog het etlike vrouesoldate opgelewer wie se militêre loopbaan deur dapperheid en uithouvermoë gekenmerk is. Molly Pitcher, ook bekend as Mary Hays is seker die bekendste van dié vroue. Sy het gewondes op die slagveld verpleeg en vir hulle water aangedra. Nadat haar man sy pos as kanonnier by die Slag van Monmouth (1778) nie meer kon volstaan nie, het sy dit oorgeneem en die kanonvuur voortgesit. Hoewel sy hierna tot sersant bevorder is, het sy in die geskiedenis as 'Kaptein Molly' bekend gestaan, ' $n$ naam wat sy as gevolg van haar besondere kraginspanning verdien het. ${ }^{6}$

Op eie bodem is die oorlogsugtige afdeling van die Batlokwa (Sotho) stam aan die begin van die negentiende eeu deur die legendariese koningin Mantitisi in 'n reeks stamoorloë gedompel. In haar verwoestingsoorloë het sy verwarring en verstrooidheid onder die groepe in die gebied tussen die Vaal- en Oranjeriviere versprei. Sy het soms haar magte, die Mantatees, wat na haar vernoem is, self gelei. $^{7}$
Die Voortrekkervrou, Susanna Catharina Smit het nou wel nie die wapen opgeneem nie, maar 'n voorbeeld van haar onverskrokkenheid is haar sterk woord aan die Britse kommissaris, adv Henry Cloete, wat die Trekkers aangeraai het om hulself aan die Natalse regering oor te gee. Die Voortrekkervroue het 'n privaat onderhoud van twee uur lank met hom in Pietermaritzburg gehad en hom van hul teenslae en lyding vertel. Aan die einde van ' $n$ vurige adres het Susanna verklaar dat die vroue kaalvoet oor die Drakensberg sou terugkeer, alvorens hulle aan die Britse regering onderdanig sou wees. ${ }^{8}$

Gewapende Afrikanervroue aan die Natalse front was luidens Bakkes aktief in die loopgraafstryd tydens die slag van Pietershoogte op 27 Februarie 1900. Asof dit niks ongewoons was nie, meld Jeans in sy beskrywing van die vlootbrigade se deelname aan die stryd in Natal dat baie vroue en kinders in die loopgrawe gewond is. ' $n$ Britse soldaat het aan sy vrou geskryf oor die vreesaanjaende gesig van meer as sestien gewapende vroue wat in die loopgrawe doodgeskiet is voordat hulle kans gehad het om terug te trek. Bakkes noem die geval van 'n sekere Helena Herbst Wagner van Zeerust wat na die

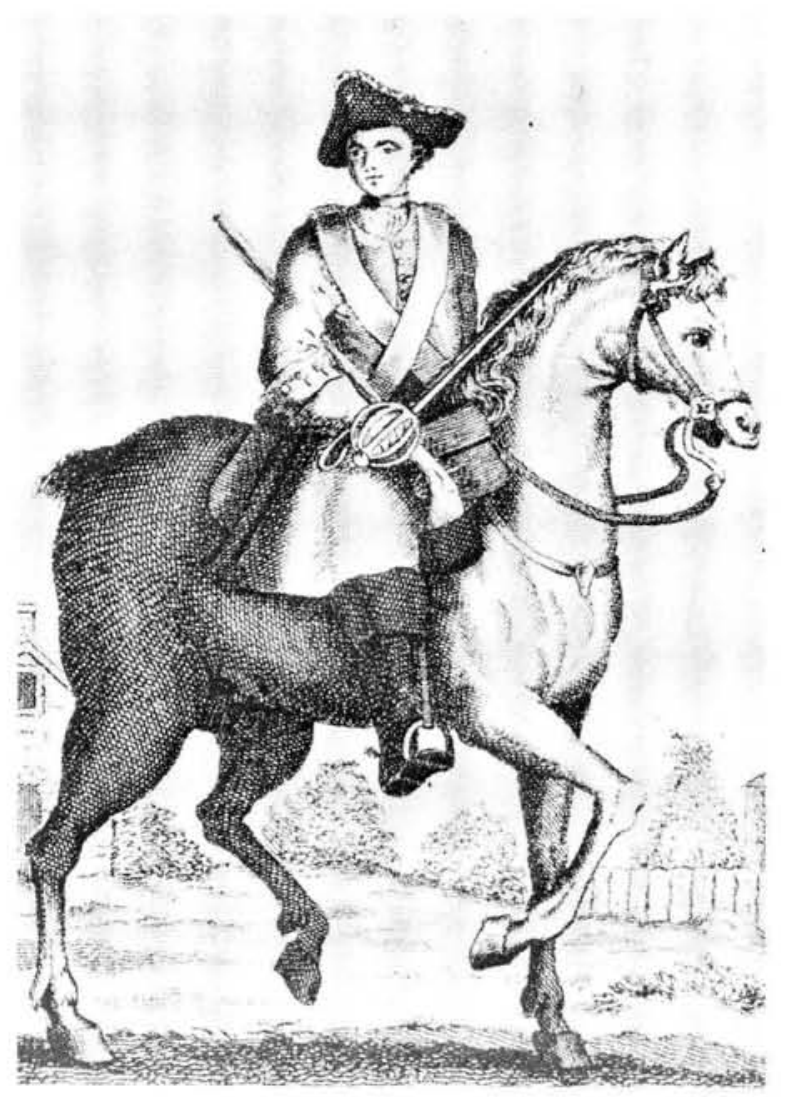

Christian Ross (Kit Welsh) in die uniform van 'n berede soldaat van die 'Scots Greys'. - Foto: 'Women in Battle' deur John Laffin. 
dood van haar baba haar man na die Natalse front sou gevolg het. Sy was gewapen en vermom in mansklere en toe sy hom nie kon vind nie, het sy by die Johannesburgse kommando aangesluit. Sonder om haar identiteit te openbaar het sy aan die veldslae by Spioenkop, Vaalkrans en Pietershoogte deelgeneem. ${ }^{8 A}$

In die laaste helfte van die negentiende eeu het die konings van Siam en van Dahomey elk 'n uitgesoekte korps vrouesoldate gehad. In Siam het die vrouesoldate as die koning se persoonlike wagte gedien. Die eenheid het uit vierhonderd vroue bestaan wat as uniform spoggerige wit en goue rokke gedra het. Hulle is net gebruik om die koning te beskerm as hy in 'n gevaarlike situasie sou wees. $^{9}$

Koning Gezo van Dahomey in Wes-Atrika, het sy vrouesoldate aan 'n opleidingskursus onderwerp waarin hulle teen mekaar gestoei met spies geveg en lang afstand hindernisresies afgelê het. 'n Vrouekryger het outomaties vrou van die koning geword en kon eers 'n geslagslewe hê nadat sy uit die korps bedank het aangesien ' $n$ swanger soldaat vir die koning waardeloos was. Die bekende leidster van hierdie soldate was Seeh-Dong-Hong-Beh. Die Dahomey vrou het weens die werking van twee invloede uit Afrika-oorlogvoering verdwyn $\mathrm{nl}$ die invloed van kolonisasie en 'n groeiende ongeduld van die mans wat nie met die beste vroue kon trou alvorens hulle leërdiens nie afgehandel is nie. ${ }^{10}$

\section{Klemverskuiwing: Ondersteunde rol teenoor dié van militêre vegter}

'Battle dress is a thing made by hands, it is a thing of the spirit and the soul. Numerous organizations worked with the troops at home and abroad in both World Wars and Korea in other than United States uniform'.

\section{a. Ondersteunende rol}

Van die vroue in uniform het die verpleegsters nog altyd die spit afgebyt. In 1854 het die pionier leërverpleegster, Florence Nightingale haar eerste veertig verpleegsters na die Krim Skiereiland geneem wat die eerste veldtog was waarop die vrou amptelik.as verpleegster erken is. Die Britse leër het in 1881 ' $n$ verplegingsdiens gestig en in 1897 is ' $n$ reserwe gevorm. ' $n$ Totaal van 1400 verpleegsters is gedurende die AngloBoereoorlog (1899-1902) na Suid-Afrika gestuur. Uit die verplegingsdiens wat in 1902 in Groot-
Brittanje gestig is, het die verpleegsters vir albei Wêreldoorloë gekom. ${ }^{12}$

'n Paar Nieu-Seelandse verpleegsters het tydens die Tweede Anglo-Boereoorlog van 1899-1902 gedien. Die verplegingsdiens is in 1911 gestig. Vrouewerk het bestaan uit eerstehulp, hospitaalwerk en klerklike werk. ${ }^{13}$

\section{Twee wêreldoorloë}

Gedurende die Eerste Wêreldoorlog het 'n Engelse tweemanskap, Elsie Knocker en Mairi Chrisholm in België bekend geraak as die vroue van Pervyse. Hulle het ' $n$ noodhulppos by die loopgrawe opgerig waar soldate kon rus voordat hulle gewondes na die hospitaal vervoer het. ${ }^{14}$

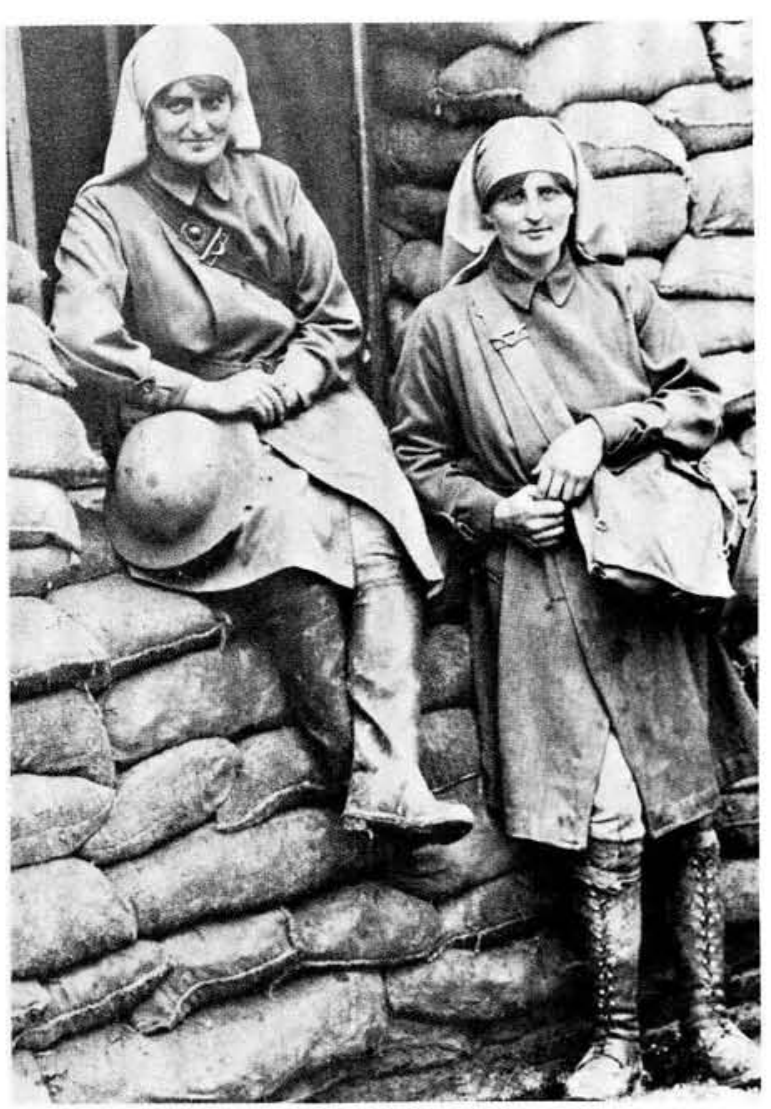

Barones T' Sorclaes en Mairi Chrisholm buite hulle pos te Pervyse. - Foto: 'Women in Battle' deur John Laffin.

Tydens die Tweede Wêreldoorlog het ' $n$ groot aantal Australiese vroue tussen die ouderdomme van 14 en 65 jaar op 'n direkte wyse met die oorlogpoging gehelp. Die oudste organisasie van die Australiese leër is sy verplegingsdiens wat voor 1900 gestig is en in alle oorloggeteisterde gebiede gedien het. $^{15}$ 
In Kanada het die verplegingskorps in 1885 ontstaan toe 'n Moeder Owerste met 'n aantal verpleegsters tydens die Noord-Westelike Rebellie na die front gegaan het. In 1907 het die verplegingsdienste ' $n$ intergrale deel van die leër se mediese korps geword. Gedurende die Tweede Wêreldoorlog is vrouekorpse in die leër, lugmag en vloot gestig. ${ }^{16}$

Volgens Johanna Brandt in haar alombekende werk, 'Die Kappiekommando' was daar Boervroue wat kommando's waarin hulle mans gedien het, gevolg het. Die vroue het vir hul mans gekook en herstelwerk verrig. Mev Nicholson van Pietersburg het in 1899 onder genl Grobler as verpleegster gaan werk toe haar man en 12-jarige seun by die kommando aangesluit het. Sy het deur haar optrede die lyding van vele verlig. ${ }^{17}$

Die enigste Italiaanse vroue in uniform gedurende die twee Wêreldoorloë was die Rooi Kruis werkers en die vrywilligers wat die eintlike verpleging gedoen het. ${ }^{18}$

Die Verenigde State van Amerika het in 1901 'n verplegingsdiens ingestel en aan hospitaalskepe,

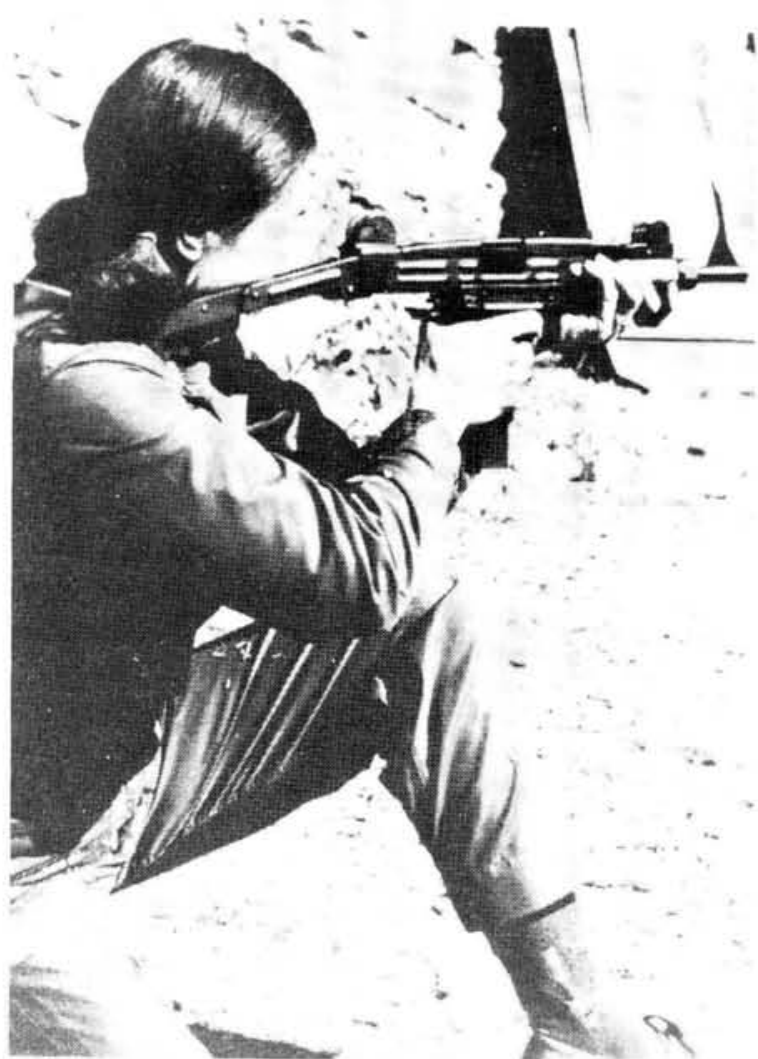

Vrouesoldate in die SAW ontvang teenswoordig nie net opleiding in die gebruik van meganiese toerusting nie, maar ook die gebruik van vuurwapens moet onder die knie gekry word. - Foto: 'Paratus' Feb 1977.

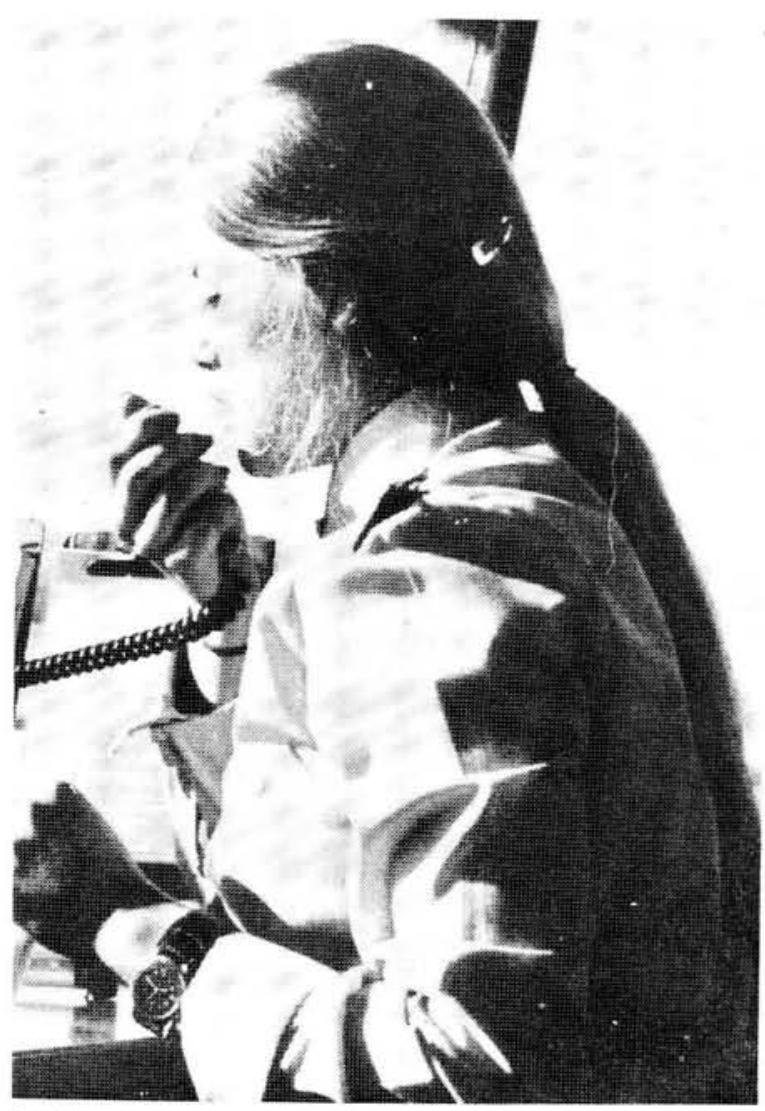

Radar operatrises van die SA Lugmag word teenswoordig vegterbeheerders genoem. Hule stel die vegvliegtuie in kennis watter bewapening en aanvalstegniek die effektiefste is in 'n bepaalde situasie en stuur die vliegtuig mbv radar op sy teiken af. Menselewens en toerusting ter waarde van miljoene rande is in hulle hande. - Foto: ‘Paratus', Feb 1977.

wat 'n tak van Mediese Dienste was, toegesê. Gedurende die oorlog van 1914-1918 het vroue in die Amerikaanse Rooikruis gewerk. Diensorganisasie soos die WAC (Women's Army Corps), die WAF (Womens Air Force) en die WAVS (Women's Auxilliary Voluntary Service) en die WASPS (Womens Air Force Service Pilots) is almal gedurende die Tweede Wêreldoorlog in Amerika gestig. ${ }^{19}$

Gedurende die Eerste Wêreldoorlog het die verpleegsters van Suid-Afrika in Oos-Afrika, Europa en in Suid-Afrika diens gedoen. Verpleegsters wat na afloop van die vyandelikhede van die Tweede Wêreldoorlog teruggekeer het, is deur die oppermatrone in Suid-Afrika, mej. C. A. Northard, vir hulle optrede geloof: ... To those who have sacrificed their lives in their effort to save the lives of others; I find no words adequately pay tribute to such sacrifices. ${ }^{20}$

Die Suid-Afrikaanse vrou het nie agtergebly gedurende die Tweede Wêreldoorlog nie, maar 
het haar deel in uniform in die vrouehulpmag en die vrouehulpleërdiens asook in die onderskeie Hulpdienste en die Militêre Verplegingsdiens gedoen. Die Hulpdienste het honderde vroue opgelei om in oorlogsfabrieke te werk, poskantore te beman, seiners te wees en vir die soldate klere te maak en te brei. Kantienafdelings vir die soldate is deur hulle beman en rehabilitasie vir gewonde soldate is deur hulle gedoen. Kinders wie se moeders by die Hulpdienste aangesluit het, is in bewaarskole en kleuterskole versorg. Die vloot het vroue radio tegnici gehad en die lugmag het vroue as fotografiese assistente aangehou. ${ }^{21}$ Vroue word tans in ' $n$ verskeidenheid van hoedanighede in die SAW aangewend.

Voor die Tweede Wêreldoorlog het daar geen vroue by die Duitse Weermag aangesluit nie. Later het die mannekrag tekort 'n verandering veroorsaak en drie klassifikasies vroue is in diens geneem $\mathrm{nl}$ klerklike hulptroepe, teenvlugvaartuigartillerie hulptroepe en seinkommunikasie hulptroepe. ${ }^{22}$

Met die uitbreek van die Tweede Wêreldoorlog wou vroue graag by die gewapende magte aansluit. In beleërde Brittanje was die dra van 'n uniform belangrik 'for it helped to create the feeling of solidarity that Winston Churchill among others knew was vital for survival. A uniform 1939-45 carried not only status but engendered immense emotional satisfaction'. 23

Die twee Wêreldoorloë het verskeie Britse vrouedienste die lig laat sien $\mathrm{nl}$ dié van die Vloot (Womens Royal Naval Service - WRENS), die leërorganisasies (Womens Royal Army Corps WRAC en die Womens Auxilliary Army Corps WAAC) en lugmagorganisasies (Womens Royal Air Force - WRAF en die Womens Auxilliary Air Force Service - WAAFS). Ander hulporganisasies was die oorlogbystandsdiens (British War Relief - BWR), 'n veelomvattende spyseniersdiens wat ekstra kos en drank aan die manne in uniform voorsien het (Navy, Army, Air Force Institute - NAAFI), 'n vermaaklikheidsdiens (Entertainments National Service Association ENSA), die Vroue Legioen (Womens Legion $W L$ ) en die vrywilligerdiens (Womens Voluntary Service - WVS). ${ }^{24}$

\section{b. Militante Vegters}

Indien die vrou met 'n muntstuk vergelyk word, dan is kruis die ondersteunende en dienende sy van haar en munt die aggressief-opstandig vegtende kwaliteite wat sy besit en wat soms in 'n oorlogspoging na vore kom. Gedurende die Twee Wêreldoorloë het vroue enige soort werk in die landbou, industrie en hulporganisasies gedoen om alle weerbare mans vir die gevegsdiens beskikbaar te stel. Tog was daar die enkele vegtende vroue wat hulle land se naam met die geweer in die hand hoog gehou het.

lerland se geskiedenis sou nie volledig gewees het as hy nie sy rebellieleidster en vegter opgelewer het nie. Die gravin Constance Markievicz het in dié hoedanigheid aan die eerste Wêreldoorlog deelgeneem. Sy is telkens in die tronk gestop en het keer op keer na ontslag, na die guerrillalewe teruggegaan. Haar militêre loopbaan het geeïndig toe sy vir vyf dae die wapen teen die lerse Republikeinse Leër (IRL) opgeneem het. ${ }^{25}$

Die aandeel van vroue in die IRL gedurende 1916-22 verdien vermelding. Almal was nie in uniform nie, maar die meerderheid was aan die 'Cumann-nam Ban' of die Vereniging van Vroue verbonde. Hulle het die moeilikste opdragte van die gevegsmagte gedeel deur boodskappe, plofstowwe en ammunisie te hanteer. Hulle het deur die land gereis met geheime boodskappe en gewondes verpleeg. Vir baie vroue was die lewe hard en gevaarlik. Teen 1915 het sommige vroue wel uniforms gehad. Die verplegingsdiens wat in 1922 gestig is, het weer gedurende die Tweede Wêreldoorlog funksioneer. ${ }^{26}$

Die Russiese vrou het 'n leeue-aandeel in die verdediging van haar land gehad. Gedurende die Eerste Wêreldoorlog het sy die Bataljon van die Dood gevorm met Madame Botchkoreva, die weduwee van ' $n$ voormalige vegtende kolonel as leidster. 'The women of Russia joined hands in a supreme act of self-sacrifice, a vain endeavour to save the honour of the country's manhood'. ${ }^{27}$ Die vroue het besluit om te sterf alvorens hulle gevange geneem word, vandaar kan die naam van die bataljon verklaar word.

Hulle het die Winterpaleis teen die rewolusionêres in 1917 verdedig en is byna uitgewis. Afgesien van die Bataljon van die Dood het baie boervroue uniform aangetrek en langs die mans geveg. Gedurende die Eerste Wêreldoorlog is vroue in die gewapende magte ook gebruik om die logistiese werk te verrig. Hoewel vroueoffisiere in die politieke departement gewerk het, was die belangrikste taak van die vrou die industrie. ${ }^{28}$

Russiese vrywilligers van beide geslagte het in 1927 'n landswye organisasie gevorm $\mathrm{nl}$ die 
OZOAVIAKHIM (die vereniging van die bevordering van lugvaart en chemiese verdediging). Jong mense is as vlieëniers en valskermspringers en in militêre onderwerpe opgelei. ${ }^{29}$

Tydens die Tweede Wêreldoorlog het baie vroue in die gevegseenhede van die Rooi Leër gedien. Maria Baide was een van die eerste vroue wat die hoogste toekenning, 'Held van die Sowjet Unie' verwerf het. Sy het vyftien Duitsers doodgeskiet en lewendig, dog gewond na haar linie teruggekeer. Nog ' $n$ Russiese heldin, Alexandra Boiko het saam met haar man 'n tenk gekoop waarin hulle as luitenante in etlike gevegte gedien het. ${ }^{30}$ In die oorlog het vroue in die infanteriegevegte meegedoen asook die tenks in aansienlike getalle help beman. Prominente vroue was dié in die Rooi Leër se mediese dienste aangesien sestig persent van die dokters vroue was so ook die meeste hospitaalordonnanse en verpleegsters. ${ }^{31}$

Die Duitse vrou, Hanna Reitsch het haarself as vlieënier onderskei en was die enigste vrou en burgerlike wat die Ysterkruis eerste klas gedurende die Tweede Wêreldoorlog verwerf het. ${ }^{32}$

Weens toenemende buitelandse druk teen Japannese emigrasie, ontwikkeling van militêre wapens en nuwe beleidsrigtings, het die Japannese Leër in die vroeë dertigerjare besluit om vroue offisieel te organiseer. 'n Nasionale Vrouevereniging is gevolglik in 1932 gestig. ${ }^{33}$

Volgens kol Nakamura Akihito was die doel van die National Defence Womens' Organisation: 'a spreading and deepening among Japanese women belief in the Japanese military values like familism, the soldier ethos and concepts of good citizens are good soldiers and all citizens are soldiers. ${ }^{34}$

\section{Spioenasie deur vroue}

Vroue in die Spioenasiediens het wel nie hulle werk in uniform gedoen nie, maar is tog deur militêre owerhede betrek om belangrike werk te doen waarvoor mans nie gebruik kan word nie. Die beroepsrisiko van alle spioene, ten minste in oorlogstyd is die dood en dus verdien vroue vermelding. Spioenasie is beskou as ' $n$ terrein waarop die man alleenreg het en vroue soos Belle Boyn, Elizabeth van Lew, Edith Cavell en Elsbeth Schragmüller het daarom des te meer uitgestaan.

Elsbeth Schragmüller was die Duitsers se geheimsinnige 'Mademoiselle le Docteur'. Sy was ' $n$ intelligente, geleerde vrou met ' $n$ doktorsgraad in die filosofie. Haar metodes was die van terrorisme en sy het 'n spioenasieskool in die Belgiese stad Antwerp opgerig. Sy was aan die hoof van geheime organisasies in Brittanje, Frankryk tot by Switserland. Haar vyande het haar die 'Queen of Spies' of 'Tiger Eyes' genoem. Van haar word gesê: .... her patriotic obsession led to the extremities of sadism'.35

'n Spioen wat meer publisiteit gekry het as wat sy verdien het, was die dame, Margaret Gertrud Macleod of beter bekend as Mata Hari. Sy het vir die Duitse Spioenasiediens gewerk en het vriende in hoë kringe in Duitsland, Frankryk en die Europese lande gehad. Tog kon nie een van haar vriende haar doodsvonnis versag nie. ${ }^{36}$

Gedurende die Tweede Wêreldoorlog het vroue in spioenasie betrokke geraak soos nog nooit tevore nie. Tussen 1939 en 1945 het dosyne onverskrokke Engelse, Amerikaanse, Russies, Franse en Duitse vroue vyandige lande binnegesluip op soek na inligtingsmateriaal. Wanneer hulle gevang is, was die behandeling nog harder as dié wat hulle manlike kollegas moes verduur. ${ }^{37}$

Verskeie vereistes, kwalitıkasıes, eienskappe en kenmerke is aan die vroulike spioen toegedig. 'n Vrou moes volgens sommige mooi wees om as spioen te kwalifiseer. 'A woman spy must be beautiful - tradition demands it'. Tog is dit waar dat die suksesvolle spioen, manlik of vroulik, onopsigtelik moes wees. ${ }^{38}$ Die vrou se emosionele samestelling maak haar volgens sekere skrywers ' $n$ veiligheidsrisiko: 'The traditionalists believe that women are more likely to fall into emotional entanglements, adding yet another hazard to effective and secure field work. ${ }^{39}$ Tog beweer sekere mense dat sy landsgeheime beter as mans kan hous. Die vrou doen haar werk as boodskapper veel beter as die manlike spioen. ${ }^{40}$

\section{Na-oorlogse periode}

\section{VROU MEER MILITANT-VERDEDIGEND}

Gesien teen die agtergrond van Israel se geskiedenis as militêr parate staat waarin selfs sy vroue diensplig doen, is dit nie vreemd dat die Jodin Bracha Fuld in 1944 gehelp het om die Britte in Palestina te verslaan nie. Op 18-jarige leeftyd was sy 'n offisier instrukteur van Joodse vrouesoldate, het haar eie peloton gelei, verskeie militêre afdelings gekommandeer en deelgeneem in die slag van Sarora. ${ }^{41}$ In 1948, die jaar van Israel se onafhanklikheidsoorlog, het vroue met 'n 
geweer in die hand langs die Israeli mans geveg. ${ }^{42}$

Met die Sewedaagse oorlog in 1967 het vroue as seiners in die Megev woestyn gedien. Ander het in die Operasionele kamer gewerk as telefoniste en was die kontak met bevelsposte. Sommige meisies moes hospitaalwerk doen en ander is met die opvoeding van kinders betrek. Vroue was nie op die front benodig nie en is nie aan gevaar blootgestel nie. ${ }^{43}$

In 1959 was daar sowat 2500 vroue in Nasionaliste Sjina in uniform onder bevel van 'n generaal-majoor wat in bevel van verpleging was. Hierdie vroue se pligte was omtrent soortgelyk aan dié van hulle kamerade in ander leërmagte. ${ }^{44}$

Uit die Mekong Delta het die Vietnamese vrou, Ho Thi Que, wat bekend was as 'The Tiger Lady of the Delta' sowat vyftig jaar gelede beroemdheid verwerf. Sy was adjudant van 'n bataljon en het haar manne in die aanval gelei. Sy het drie toekennings vir haar dapperheid ontvang en die Vietkong guerrillas is deur haar magte verskrik. Sowat 3000 Vietnamese vroue het in 1966 in
Suid-Vietnam se leër geveg. Die vrywilligers het aanvanklik van Saigon af gekom.

Steeds in Vietnam, word die Min Top vroue in 1962 aangetref wat almal skerpskutters was en meedoënloos opgetree het. Van hulle word gesê: 'All marksmen, they picked off the guerrillas who ran and when a man fell they clubbed him to death with rifle bi'tts'. ${ }^{45}$

Westerse militêre kenners beweer dat die enigste vegtende vroue van die moderne tyd wat met die Vietnamese meisies vergelyk kan word sommige Kikuyu vroue is, wat saam met die Mau Maus in 1950 geveg het. ${ }^{46}$

Die jongste Britse regiment, die Ulster Defence Regiment (UDR), ' $n$ infanterie regiment, het sy eie vroue-afdeling gevorm. Die doel waarom die UDR vroue in diens geneem het, was om terrorisme doeltreffend te kan weerstaan. In 1973 het opleiding begin aangesien genoeg vroue toe aangesluit het. Die UDR is ' $n$ eksperiment aangesien vrouesoldate binne ' $n$ Britse regiment in diens geneem is en in elke aspek gelykheid met die mans geniet behalwe dat wanneer hulle operasioneel is, is hulle ongewapend. ${ }^{47}$

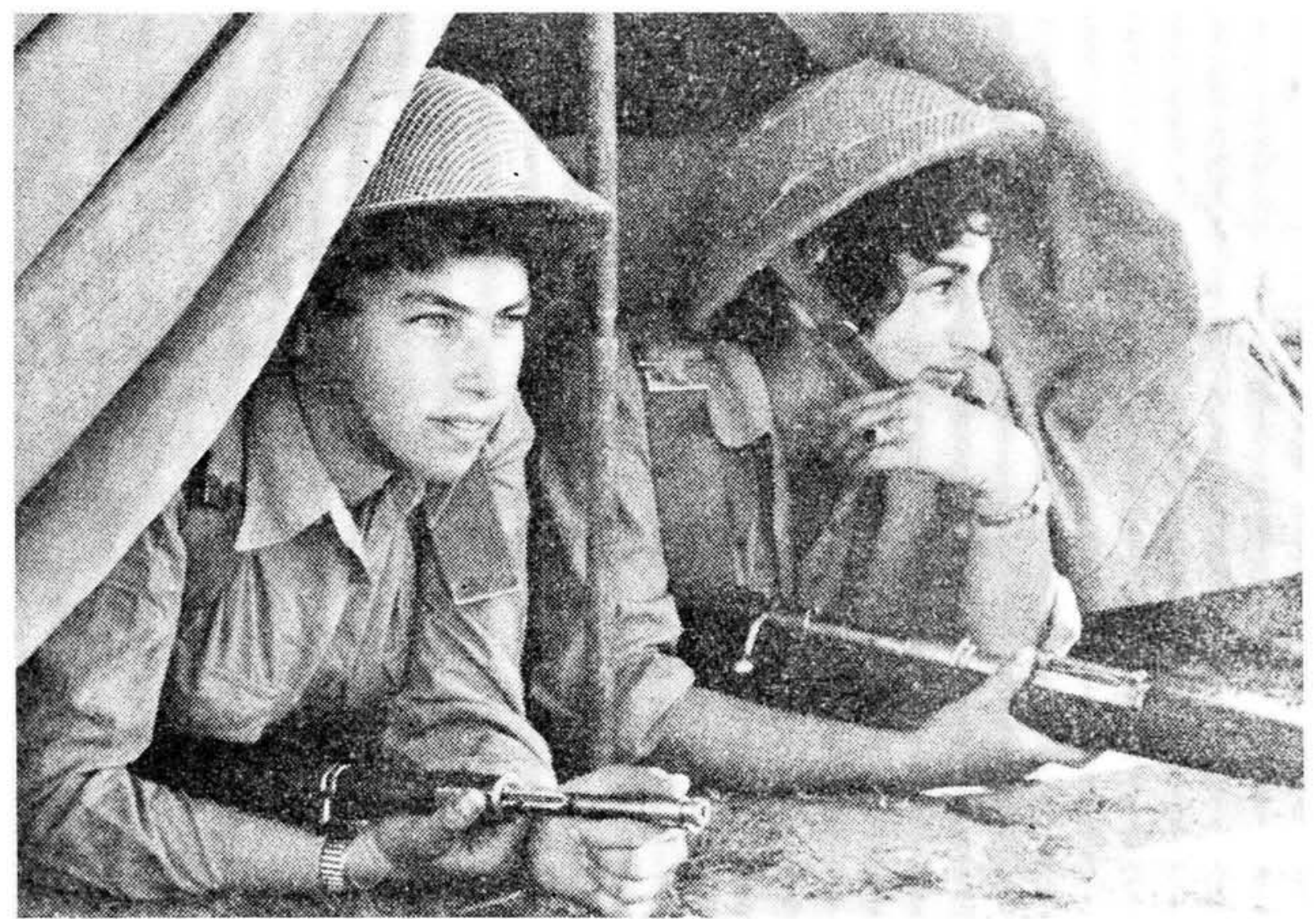

Israell vrouesoldate sien soldaat-wees in 'n baie ernstige lig en kan daardie gewere wel deeglik hanteer. - Foto: 'Kommando', Aug 1965. 
In die na-oorlogse era het terrorisme en by name stedelike terrorisme met rasse skrede toegeneem. Die Baader-Meinhof bende het verskrikking in Wes-Duitsland aan die einde van die sestiger- en die begin sewentigerjare gesaai. Van die aktiewe bendelede was vroue, oa Gudrun Enslin. Ulrike Meinhof en Petra Schlem. ${ }^{48}$

Sedert die eerste Wêreldoorlog het vroue al hoe meer in militêre konflikte betrokke geraak. In die Verenigde State van Amerika en elders word daar vandag voorspraak gemaak vir die vrouesoldaat om aan die geveg te kan meedoen. ${ }^{49}$

Aangesien Amerika die leiding neem wat betref sovele aspekte van belang in die wêreld, sou dit werklik vergesog wees om te beweer dat dit nie meer lank sal wees nie of die vrou is terug in die rol van Jeanne d'Arc van ouds?

Lt E. M. Meyers (SAV), MA (HOD) is verbonde aan die Dokumentasiediens van die SAW.

\section{Voetnote}

1. J. Laffin: Women in Battle, Abelhard-Schuman, London, 1967, pp 17-19.

2. Ibid, $\mathrm{pp} 33-34$

3. Ibid, $p 36$.

4. Ibid, pp 40,41 .

5. Ibid, p 32.

6. Ibid, pp 100-105

7. A. T. Bryant: Olden Times in Zululand and Natal, Longmans Green and Co, New York, 1929, pp 151, 152; D. R. Morris: The Washing of the Spears, Simon and Schuster, New York, 1965, pp 57, 58.

8. W. J. de Kock (red): Dictionary of South African Biography, Vol I, Tafelberg Uitgewers, Kaapstad, 1968, p 730.

8A. C. M. Bakkes: Die Britse Deurbraak aan die Benede-Tugela op Majubadag 1900, Sentrale Dokumentasiediens SAW, Publikasie No 3, Pretoria, 1973.

9. Laffin, op cit, pp 46, 47.

10. Ibid, pp 49-51.

11. Volgens die eerste kolonel van die WAAC, Oveta Culp Hobby is vegtenue iets geesteliks. J. R. Power: Brave Women and their Wartime Decorations, Vantage Press, New York, 1959, pp 42, 43.

12. Power, op cit, pp 65-71.
13. Ibid 59

14. Laffin, op cit, pp $54,55$.

15. Power, op cit, p 55.

16. Ibid, p 58.

17. J. Brandt: Die Kappiekommando, Hollandsche-Afrikaansche Uitgewers, 1915, p 216; E. Hobhouse (red): War Without Glamour or Women's War Experiences written by themselves 1899-1902, Nasionale Pers Bpk, Bloemfontein, 1924, pp 67-68.

18. Power, op cit, $\mathrm{p} 39$.

19. Ibid, pp 65-71.

20. A. E. van Jaarsveldt: 'Die Suid-Afrikaanse Militêre Verplegingsdiens', Militaria, 8/2, 1978, p 65.

21. P. C. Batley: Home-Front Workers, The Nongaai, Vol 35 no 4, April 1944 , pp 387-390.

22. Laffin, op cit, $p$ 76; Power, op cit, p 38

23. Laffin, $p 66$

24. Power, op cit, pp 50-53.

25. Laffin, op cit, pp 60-61.

26. Power, op cit, pp 32 en 33

27. Laffin, op cit, $\mathrm{p} 57$.

28. E. O'Ballance: The Red Army, Faber and Faber, Londen, 1964, p 98; A. S. Hooper: The Soviet Fighting Forces, Frederick Muller, Londen, 1949, p 36.

29. O'Ballance, op cit, p 107; Hooper, op cit, $p 35$.

30. Laffin, op cit, p 71 .

31. L. B. Ely: The Red Army Today, The Mulitary-Service-Publishing Company, Pensylvania, 1951, p 132.

32. Laffin, op cit, $p 76$.

33. R. J. Smethurst: A Social Basis for Prewar Japanese Militarism, The Army and the Rural Community, University California Press, Los Angeles, 1974, pp 44, 45.

34. Ibid, 48.

35. G. Aston: Secret Service, Faber and Faber, Londen, 1968pp 146, 147; R. W. Rowan et al: Secret Service Thirty-Three centuries of Espionage, Hawthorne Books, inc, New York, 1967, p 531.

36. Aston, op cit, p 536; Rowan, op cit, pp 149-151; B. Newman: Secrets of the German Espionage, Robert Hale, London, 1940,pp $161-165$.

37. Aston, op cit, $p 646$.

38. Hale, op cit, $\mathrm{p} 166$.

39. Rowan, op cit, p 143; Aston, op cit, p 647.

40. Hale, op cit, p 165.

41. Laffin, op cit, $p 76$.

42. S. Robant: The Israeli Soldier, Profile of an Army, New York, 1970, p 3

43. C. S. Landrum: 'The Israeli Fighting Women, Myth and Facts', Air University Review, Vol 30 no 1, Nov-Des 1978, pp 45-46.

44. Power, op cit, $\mathrm{p} 32$.

45. Laffin, op cit, $p 78$.

46. Ibid, $p 78$.

47. A. Greenfich: 'Women of the UDR', British Army Review, Des 1975, p 32.

48. P. B. Pirnie: 'The Urban Guerilla: West German Terrorists', Military Police Law Enforcement Journal, vol 4 no 2, Summer 1977, pp 20-21.

49. P. L. Moorcraft 'Women at War in Rhodesia', Armed Forces, Vol 5, Nov $1978, p 23$. 